\title{
ADDENDUM
}

\section{Nutrient availability as the key regulator of global forest carbon balance}

M. Fernández-Martínez, S. Vicca, I. A. Janssens, J. Sardans, S. Luyssaert, M. Campioli, F. S. Chapin III, P. Ciais, Y. Malhi, M. Obersteiner, D. Papale, S. L. Piao, M. Reichstein, F. Rodà and J. Peñuelas

Nature Clim. Change 4, 471-476 (2014); published online 6 April 2014; corrected after print 28 May 2014.

In the version of this Letter originally published, the following text was omitted from the acknowledgements section: 'We also thank all site investigators, their funding agencies, the various regional flux networks (Afriflux, AmeriFlux, AsiaFlux, CarboAfrica, CarboEurope-IP, ChinaFlux, Fluxnet-Canada, KoFlux, LBA, NECC, OzFlux, TCOS-Siberia, USCCC), the Office of Science (BER) and US Department of Energy (for funding the development of measurement and data submission protocols), and the Fluxnet project, whose work and support is essential for obtaining the measurements without which the type of integrated analyses conducted in this study would not be possible.' This has been corrected in the online versions of the Letter. 